PARtake: The Journal of Performance as Research Volume 3, Issue 2 - March 2021 ISSN: 2472-0860

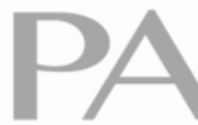

The Journal of Performance as Research

\title{
Towards a Model for Teaching PAR in the Undergraduate
}

\section{Classroom}

Oona Hatton, PhD - San Jose State University 


\section{Introduction: Developing a PAR Pedagogy}

In the summer of 2013, over 30,000 members of California's incarcerated population participated in a sixty-day hunger strike. The protest was an organized response to living conditions in the state's solitary confinement facilities, known as Security House Units (SHU), including Pelican Bay State Prison in Crescent City, California. The 2013 strike was in fact the third in a series of collective actions; the first, a three-week protest staged in July 2011, was described by criminologist Keramet Reiter as "the first moment of widely publicized mass resistance to the daily regime in California prisons in forty years." ${ }^{1}$ All protest activity was coordinated by a group of four men who had been incarcerated at Pelican Bay for over a decade. ${ }^{2}$ The strikers presented five demands to the California Department of Corrections and Rehabilitation (CDCR), but the chief issue was the practice of indefinite sentencing for individuals accused of membership in or association with a prison gang. While most internal infractions, such as assaulting another inmate, had specific sentencing guidelines, there was no time limit on penalizing gang membership. Indeed, there was no path for getting out of solitary other than to "debrief," a process through which individuals were asked to renounce their (alleged) affiliations and provide information about members, organizational structure, communication, etc.--a proposition that would doubtless endanger them upon return to the general prison population. In spite of research demonstrating that solitary confinement has lasting negative impacts after just ten days, the CDCR had roughly four thousand people locked in the SHU indefinitely. ${ }^{3}$ At the same time, CDCR leadership denied that state prisons utilized solitary confinement. ${ }^{4}$

In 2014 and 2019 I taught a performance studies course called COMM 125P: Ensemble Performance, in which the culminating assignment was a public presentation about solitary confinement in California. The first version centered on the 2013 hunger strike and CDCR policy; the second focused on the experience of a single individual incarcerated at Pelican Bay. Both iterations required students to engage in performance as research (PAR) on the same general topic, but were otherwise markedly different.

This essay draws on the two versions of COMM 125P to develop a pedagogical framework for teaching PAR to undergraduate students. My model is inspired by Robin 
Nelson's proposed elements for a "justifiable" PAR practice: making the tacit explicit, principles of composition, and building connections between "know what" and "know that." ${ }^{\circ}$ Perhaps wisely, Nelson does not offer extensive description of the three elements; nor were they originally proposed as curricular tenets. The resulting malleability allows those who teach aspiring scholartists to provide their own definitions of the elements, and to determine how they might map on to an undergraduate syllabus in performance or theatre studies. In developing the framework, I reflect on these courses from three different points of entry. I begin by comparing student learning outcomes, follow with a description of the rehearsal and performance processes, and end with a discussion on the importance of student reflections. Although each section is paired with one of Nelson's three elements, this is an artificial distinction to facilitate the systematic examination of a fluctuating and dynamic process. Because they spill across multiple areas of the curriculum — indeed, they spill over each other — the elements will not manifest so discretely in practice. Likewise, it is my hope that the multiple differences between the two courses will demonstrate that following Nelson's recommendations need not be formulaic or restrictive of course content.

\section{Institutional Habitats: The Culture of Communication Studies}

In order to establish a successful and enduring PAR program, instructors must understand and make use of the features of their institutional habitats. A unique challenge/opportunity for courses in performance practice is a fluid identity contingent on where they are located within the university system. As Shannon Jackson observes, "These differences affect how that field is understood as both a mode of critical inquiry and a site for developing different skills." ${ }^{96}$ Moreover, Jackson argues that the processes of many politically minded contemporary artists align with social scientific methods. ${ }^{7}$ As performance studies scholars housed in a Communication Studies department, in turn located within the College of Social Sciences, my colleagues and I are well positioned to frame our own work and that of our students as research. ${ }^{8}$ Additional department designations support the connection between research and praxis; each Communication Studies upper division course is categorized as either F, I, or P. The first group, standing for "fundamentals," focuses on communication theories and the second, "inquiry" 
courses, are devoted to research methods. The final group is "practice" courses, described as "the application of theoretical frameworks and research methods in specific contexts." 9 While these designations provide structure for the major course of study, they also create space for the applied nature of performance-based research (and, arguably, any research).

Equally if not more influential than program structures are the individuals who people our classrooms. Since before I began teaching at my institution in 2013, the department and much of the university have experienced impaction. The public university's opposing priorities of accommodating the highest number of students with the lowest expenditures means that there is greater demand for classes than supply. In addition, most students have family and work obligations that limit their availability. Students thus typically enroll in courses based on the time they are offered or their ability to satisfy major requirements, and not necessarily due to interest in the subject. The vast majority of students who enroll in COMM 125P thus have no performance experience and are not aware that they will be required to perform. While this can present limitations in terms of vocabulary and skill, it also removes the obstacles that can be present when students arrive in the classroom with preconceptions about what makes for a successful rehearsal process or performance. As one student's final paper indicates, chance enrollment does not preclude a potent response:

When I say that I registered for this class because there were absolutely no other classes available at the time of registration, I believe that I speak for more than half the class. But having experienced what I went through with this class, I genuinely feel sorry for those that registered for other classes and didn't get a chance to be in this one. To say that our class was a success, I first need to define what success meant to us as a class. On the first day of school, [the instructor] told us that we, as a class, were going to put on a show at the end of the semester, she explained that she has no idea what that show is going to be like or what it was going to be about but as a class, we were going to figure it out throughout the semester. In my head, I thought to myself how ridiculous that was, how are we going to put on a show if we do not even know what it is going to be about or how it is going to happen. As the semester progressed, and through our tireless work 
and effective group communication, we put on a magnificent show for people in our community that each and every one of us were proud of. ${ }^{10}$

\section{Making the Tacit Explicit: Learning Outcomes}

In spite of a department climate receptive to the axioms underlying PAR, COMM 125P's permanent course description (composed when the class was first designed ten years ago and published in the university catalog), describes the research process as exclusively text-based:

Students collaborate to conceive, write, rehearse, and produce an ensemble project culminating in a public performance. Readings and written work focus on performance as a community-building process as well as dramaturgical research for the production. ${ }^{11}$

Although research is described as central to the course, performance is not cited as a methodological component of the research process. I was chagrined to realize that this lack of acknowledgement extended to the learning outcomes I had written (see table 1). The 2014 learning outcomes fall into three categories: the first goal (fulfilled by SLO 1, $3,4)$ is about aesthetic/creative development; the second (SLO 2) is about critical thinking and research skills; the third (SLO 5) contextualizes the course within the discipline through the theoretical framework of group communication. As in the catalog description, performance is distinct from research; moreover, the modes of research and its presentation are not explicit. The 2019 learning outcomes likewise describe the task of production (SLO 1) as distinct from the task of communicating knowledge to others (SLO 2).

Table 1. Student Learning Outcomes (SLOs) for COMM 125P

SLOs $2014 \quad 2019$

SLO 1 COLLABORATE in the composition of a group performance, including
COLLABORATE in the creation of a theatrical production, including rehearsal, design, construction, 


\begin{tabular}{|c|c|c|}
\hline & $\begin{array}{l}\text { conception, rehearsal, and } \\
\text { production. }\end{array}$ & marketing, and performance. \\
\hline SLO 2 & $\begin{array}{l}\text { ARTICULATE QUESTIONS } \\
\text { then FORMULATE and } \\
\text { EXECUTE RESEARCH PLANS } \\
\text { to answer those questions. }\end{array}$ & $\begin{array}{l}\text { EXPLAIN the recent role, practices, } \\
\text { and impact of solitary confinement in } \\
\text { CA state prisons. }\end{array}$ \\
\hline SLO 3 & $\begin{array}{l}\text { CREATE individual and group } \\
\text { performances that directly engage } \\
\text { class theme and readings. }\end{array}$ & $\begin{array}{l}\text { APPLY theories of group } \\
\text { communication to the rehearsal, } \\
\text { production, and performance process. }\end{array}$ \\
\hline SLO 4 & $\begin{array}{l}\text { PERFORM in an ensemble } \\
\text { production with energy, } \\
\text { commitment, and specificity. }\end{array}$ & $\begin{array}{l}\text { CREATE and EXECUTE a marketing } \\
\text { and outreach plan to ensure the } \\
\text { greatest campus and community } \\
\text { participation. }^{\text {a }}\end{array}$ \\
\hline SLO 5 & $\begin{array}{l}\text { APPLY theories of group } \\
\text { communication in written } \\
\text { reflection on rehearsal and }\end{array}$ & \\
\hline
\end{tabular}

${ }^{a}$ Example of SLO specific to student role (Marketing and Outreach team).

In my first year teaching COMM 125P, I divided my precious class time (seventyfive minutes, twice a week) between practicing performance techniques and dramaturgical research. I introduced students to tableaux and gesture, and asked them to experiment with production elements such as costume, sound, props, and lighting. At the same time, we engaged with dramaturgical material through discussion and movement exercises. Outside of class, students were assigned weekly readings and films about solitary confinement and were asked to compose written and embodied responses. They 
also completed written assignments related to performance, such as a proposal for an activity that would facilitate audience interaction.

Early in the semester, our dramaturgical materials were substantially enriched as a result of an unanticipated opportunity. With the enticement of a substantial amount of extra credit, I persuaded a handful of students to journey two hours to the state capitol of Sacramento to attend a legislative hearing on conditions in the SHU. Packed into an overcrowded courtroom filled with family members, activists, and journalists, I lost my students but found Sheila Pinkel, a retired art professor who had been corresponding for several years with an artist at Pelican Bay State Penitentiary. Sheila had published a book of poetry, drawings, and letters from her friend Jack, who had been in solitary confinement for almost thirty years. After leafing through The World of Jack L. Morris, I purchased a copy on the spot. Jack's letters to Sheila gave insight into one person's experience at Pelican Bay; they were also an invaluable ethnographic resource, as they described the day-to-day conditions in the SHU. Most of our other readings included journalistic coverage of the strike and primary resources related to CDCR policies and practice; The World of Jack L. Morris was the most detailed account of life on the inside, and I hoped it would put a face on some of the abstract ideas and experiences with which we had been working. What I did not adequately recognize at the time was the "liquid knowledge" gained by being in the room for the hearing itself. ${ }^{12}$ The stuffy air, the unpolished speakers sharing stories at a microphone placed at the end of a crowded aisle, the long row of teenage activists from Oakland in matching black t-shirts, the nervous CDCR administrator with heavy makeup and an ill-fitting business suit, and the politicians running the hearing from a raised dais were all people deeply invested in the state's use of solitary confinement.

Illustrating artist Marilyn Arsem's observation that some performances become research for later performances, the course design for the 2019 version of COMM 125P was born out of our field trip to Sacramento. ${ }^{13}$ At the conclusion of the first class, I had written to Jack expressing gratitude for the insights his letters, poetry, and artwork had provided. We continued to correspond and I ultimately secured his permission, and that of his friend and publisher Sheila, to adapt his work into a play. That play became the performance text for the 2019 class, which would designate students as designers, an 
assistant director, stage management and marketing and outreach teams, and set construction/stage crew as well as performers. My department chair authorized me to admit students through permission number only, meaning that rather than wait to see who appeared on the first day, I recruited participants months in advance through auditions and meetings. While this practice would be standard for any theatre department, it was unprecedented for Communication Studies. More unique privileges followed: I was permitted to enroll only fifteen students--the minimum required for a class to run--rather than the typical number of twenty-five. Thanks to grants from SJSU's College of Social Sciences and the College of Arts and Humanities, we presented the play in the wellequipped Hammer Theatre Center adjacent to the university. While I designed the syllabus, recruited students, and participated in every aspect of the production process, a professional theatre director was hired as the instructor of record.

Nelson underscores that PAR practitioners must be well-versed in the many "turns" that have led (some) fields to be more accepting of evidence acquired through means other than the scientific method. ${ }^{14}$ While I agree, since most undergraduates will not go on to become specialists, rehearsing that trajectory seems less vital at this stage. However, PAR pedagogy must make explicit that its fundamental goal is to create new knowledge as well as art. The two sets of learning outcomes above share a surprising lack of acknowledgement of the role of performance in the research process, even though both courses relied heavily on embodied activity during what my Communication Studies colleagues would call the phases of data collection, analysis, and dissemination. For example, the first course included an activity where students volunteered to sit in a small room, containing only a chair, for thirty minutes. Their reflections illustrate how the experience conveyed, in small part, the physical and psychological sensations of confinement, as well as identifying its limitations. ${ }^{15}$

Going into the experiment...I expected it to be really easy and uneventful....I sat there for [what] I'm sure was no more than 3 minutes but it felt like an eternity and I had no way of knowing how long I have been sitting there and how much time I had left...I started to think about how a prisoner would actually feel in solitary confinement, it is absolutely beyond me how people can still live, and how easy it is to go insane to be locked up in a place that is absolutely torturous. ${ }^{16}$ 
I felt like I had been in the room for hours and that maybe [the instructor] had forgot that I was in the classroom and considered to pop my head out and check the clock in a classroom near by. The thought kept crossing my mind, but I stayed rooted to the chair, afraid that I would be punished for not following the rules. I was antsy and ready to leave the building and never come back on campus when I heard someone's footsteps. I listened closer and heard [the instructor's] voice coming closer. At last she opened the door and I felt a wave of relief that it was over and that I had not been forgotten. ${ }^{17}$

I can't help but think of all the inmates' attempts to relax themselves only to exit that state of mind to awaken within the same dull and barren room. ${ }^{18}$

In contrast, the 2019 course offered fewer opportunities for physical experimentation outside of the script. Nonetheless, there were plenty of moments of embodied learning; the director conducted group workshops that introduced the cast to Viewpoints techniques, and the cast learned a dance that would close the first act. Dramaturgical meetings with the whole class were largely activity and discussion-based; I also invited a local activist who had been incarcerated at Pelican Bay's SHU to speak during one of the early rehearsals. 


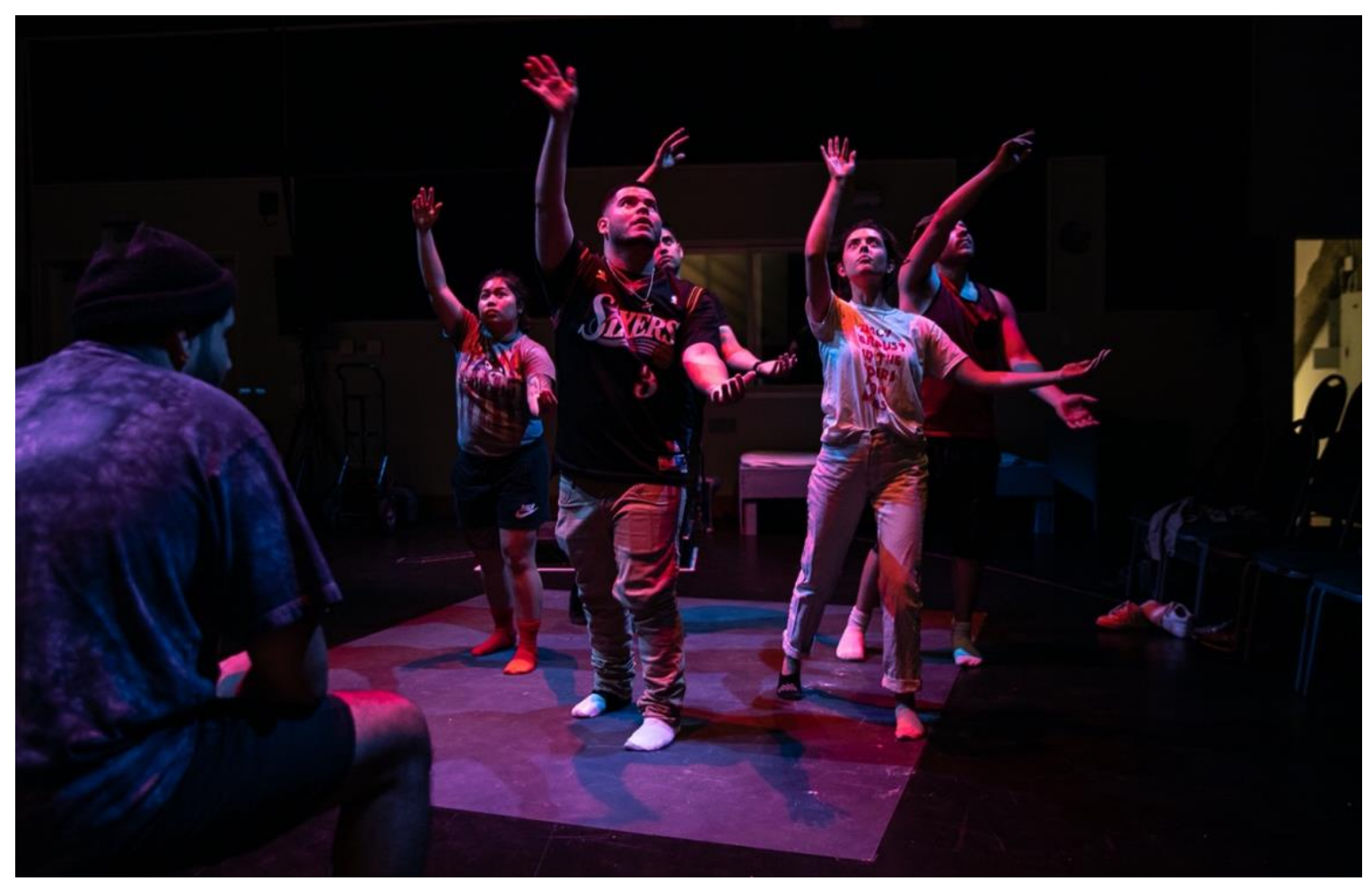

Figure 1. Dance rehearsal for See You in My Dreams, photo by @ C Peter Merts.

In addition to articulating the value of embodied and experiential learning, students also seemed aware of its challenges and limitations. Of the solitary activity one student wrote:

[T]his experiment lacked the single key ingredient to accurately simulate the Solitary Confinement experience - it was missing the overall pervasive feeling of oppression that comes hand in hand with being in a penitentiary. It lacked the tangible feelings of anger and hatred and loathing - from the guards, the public, society, the Judicial System, the other prisoners, and even seemingly the universe itself - all being directed towards you, weighing you down, filling you with fear and dread. ${ }^{19}$

Another discussed the frustrations related to collaboration.

One of the first group activities we took part in was the creation of tableaus. Right away I sensed conflict in the way we tried to create the tableaus. I wanted to position my body on a table to signify torture, but one of my classmates thought that kneeling was a better way to convey that message. Two of my classmates 
disagreed on the length of time it took to hold the position, and as a result ended up posing during different intervals which didn't convey the message properly. ${ }^{20}$

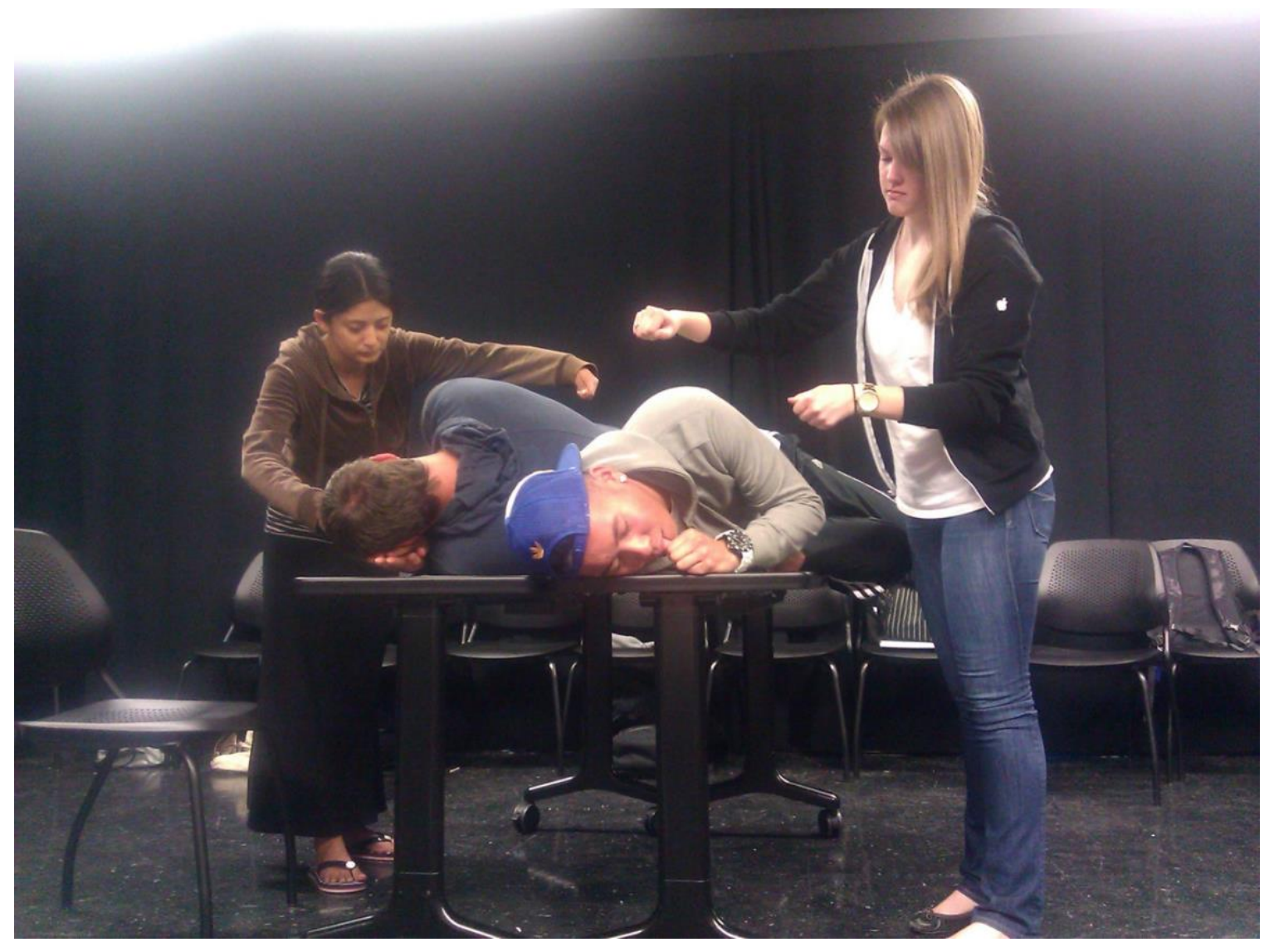

Figure 2. A Walk in Our SHUs: Rehearsal Tableau, photo by author

Cultivating a PAR-centered sensibility requires intention. Instructors can pair thematically appropriate scholarship with performance workshops in order to develop a common vocabulary for communicating about literal and symbolic embodiment. ${ }^{21}$ This can orient students to the epistemological nature of performance early in the term, laying the groundwork for critical reflections. As the term progresses, diverse assignments can demonstrate how performance might play a role in all three steps of the research process: acquiring evidence, interpreting it, and sharing it with others. Instructors can also share their own work as a model. Most importantly, PAR syllabi should include learning outcomes that underscore the role of performance in the education process (see table 2). 
CONDUCT, INTERPRET, and COMMUNICATE research through embodied practice.

COMPOSE performative responses to course material.

PROVIDE examples of how the course theme was illuminated through subjective experience.

REFLECT on the ethics of authorship and the question of how content is transformed through performance.

\section{Principles of Composition: Building the Final Performances}

In her call for a legitimizing PAR practice, Nelson is sympathetic to artists who struggle with describing their praxis in a systematic fashion. She is nonetheless firm that the effort must be made, if not in envisioning a project, then in retrospect. Articulating the compositional elements of a work prevents scholartists from being overly precious, and while it might strike some artists as reductive and even impossible, it can make one's process intelligible to those outside of the experience. 


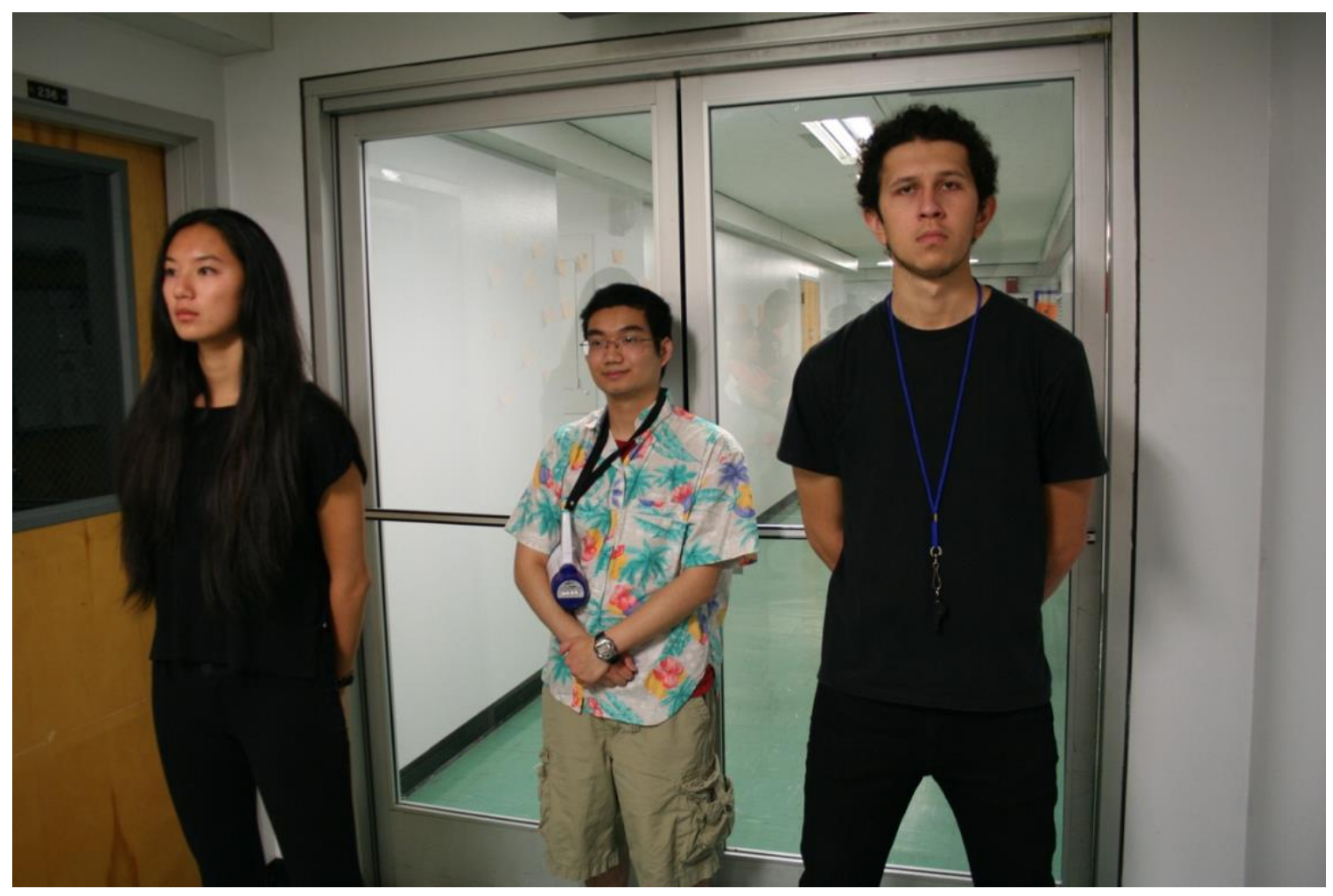

Figure 3. A Walk in Our SHUs: Guards and Tour Guide, photo by author

Towards the end of the first course, I assembled an hour-long performance composed of solo and group pieces created in class. Some works were incorporated as presented, some were layered together, others were re-assigned to new performers. The performance, which the students titled A Walk in Our SHUs: An Original Performance Exploring the California Prison System, was structured in a prologue and three acts. In one classroom, audience members checked in at a table where four unsmiling Guards asked them a series of personal questions, recording the answers on forms. An ebullient Tour Guide then ushered the group into our own classroom for the first act. The second act was presented in promenade and took place down a long adjoining hallway, where small study rooms set up as cells contained solo acts performing simultaneously. A timeline outlining the history of the hunger strikes ran along with opposite wall. At one end of the hallway a room stood open as an approximation of a SHU cell; at the far end a group of students executed movement sequences against a slide show outlining the Five Core Demands made by the hunger strikers. The Guards paced the hallway, speaking only to remind audience members to look but not step into the study rooms. After roughly 
twenty minutes of exploration, the Tour Guide shepherded the group back to the classroom where the chairs had been moved into a semi-circle for the final act.

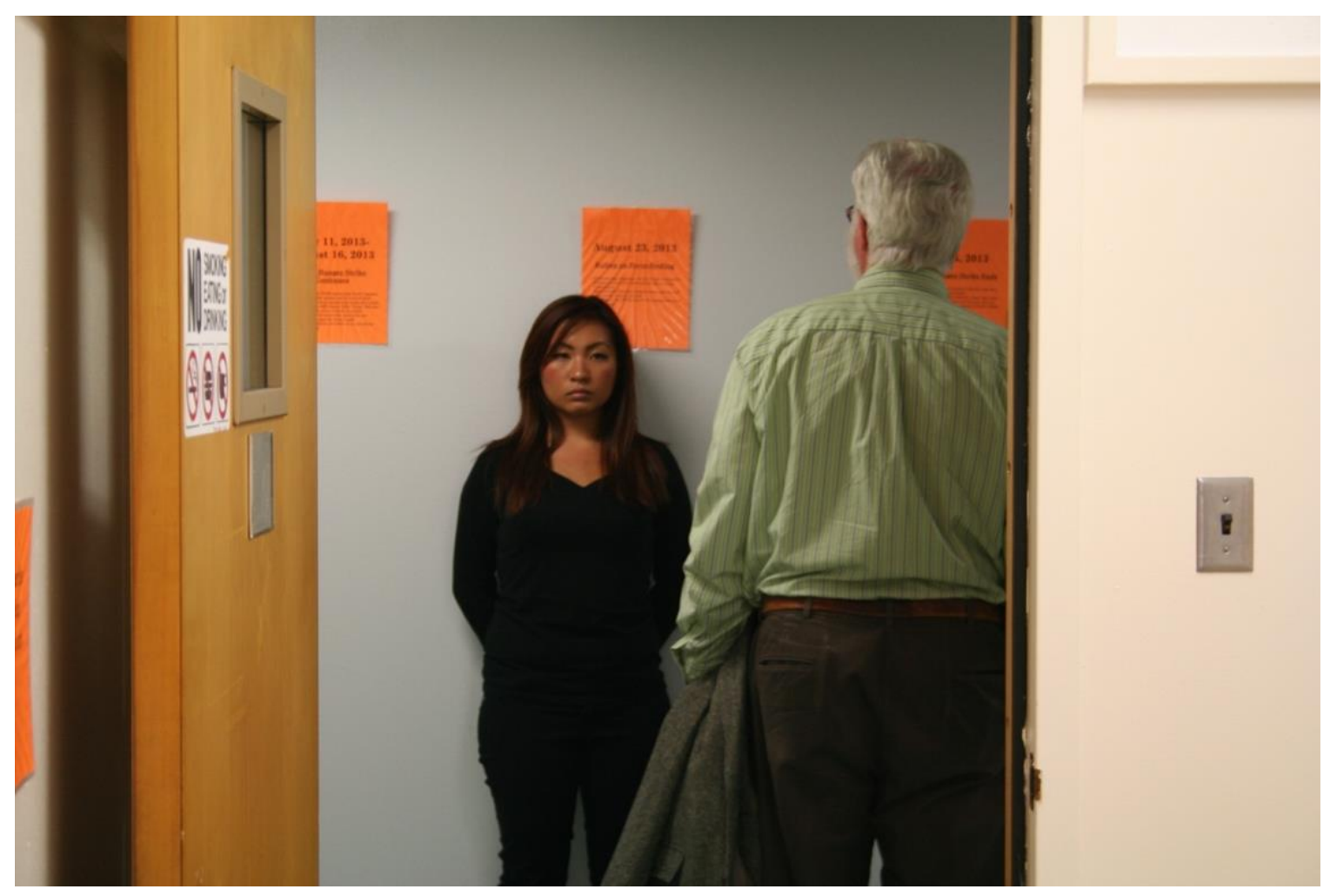

Figure 4. A Walk in Our SHUs: Guard and Audience Member, photo by author

At the beginning of the semester, I made an effort to manage student expectations about our final product. I explained that there would be no linear plot or character development. Much of the presentation would be evocative or symbolic rather than literal, and the audience would have a degree of agency--and responsibility--in navigating the performance, which I hoped would serve, as Jackson has described, as a "medium of critical exchange." 22 Performance was thus conceived as a continuation of our research as well as the opportunity to share what we had learned. This was all very difficult for most of the students to conceive, not because they were accustomed to more traditional theatre, but because most had never attended a live performance. Their conception was initially anchored in two facts: that there would be an audience, and that the show would last roughly one hour. It was only as the semester went on and they realized the work we had 
been doing in class would be the work we presented that the project began to take shape for them, and they became excited about how it would come together as a whole.

While I was gratified by the results of our labors, my sense based on final reflections was that students were more impacted by the relationships they had developed than by the issue of solitary confinement. As one noted,

Understanding the classroom codes and the language we would use when referring to the California prison system and knowing what you could contribute to the class were vital to our success. But the success of the show had more to do with the cohesion of our class and the work we all did to be together. I personally had a really great time with everybody in class and learning what it is like to be a part of a group that you want and wants you. I guess another word for that would be family. ${ }^{23}$

I had hoped students would develop an understanding of CDCR policies and practices that would lead them to question the treatment of those in solitary, and to create a performance that provided audiences a chance for critical exploration. But the connections students made with their peers felt deep and authentic while the issue of incarceration seem to remain comparatively abstract. From this I learned that just as the tone set by an instructor will reap interpersonal rewards in a way that feels organic, authentic, and effortless, the research/rehearsal process must make the subject of inquiry present and vital by scaffolding student engagement. 


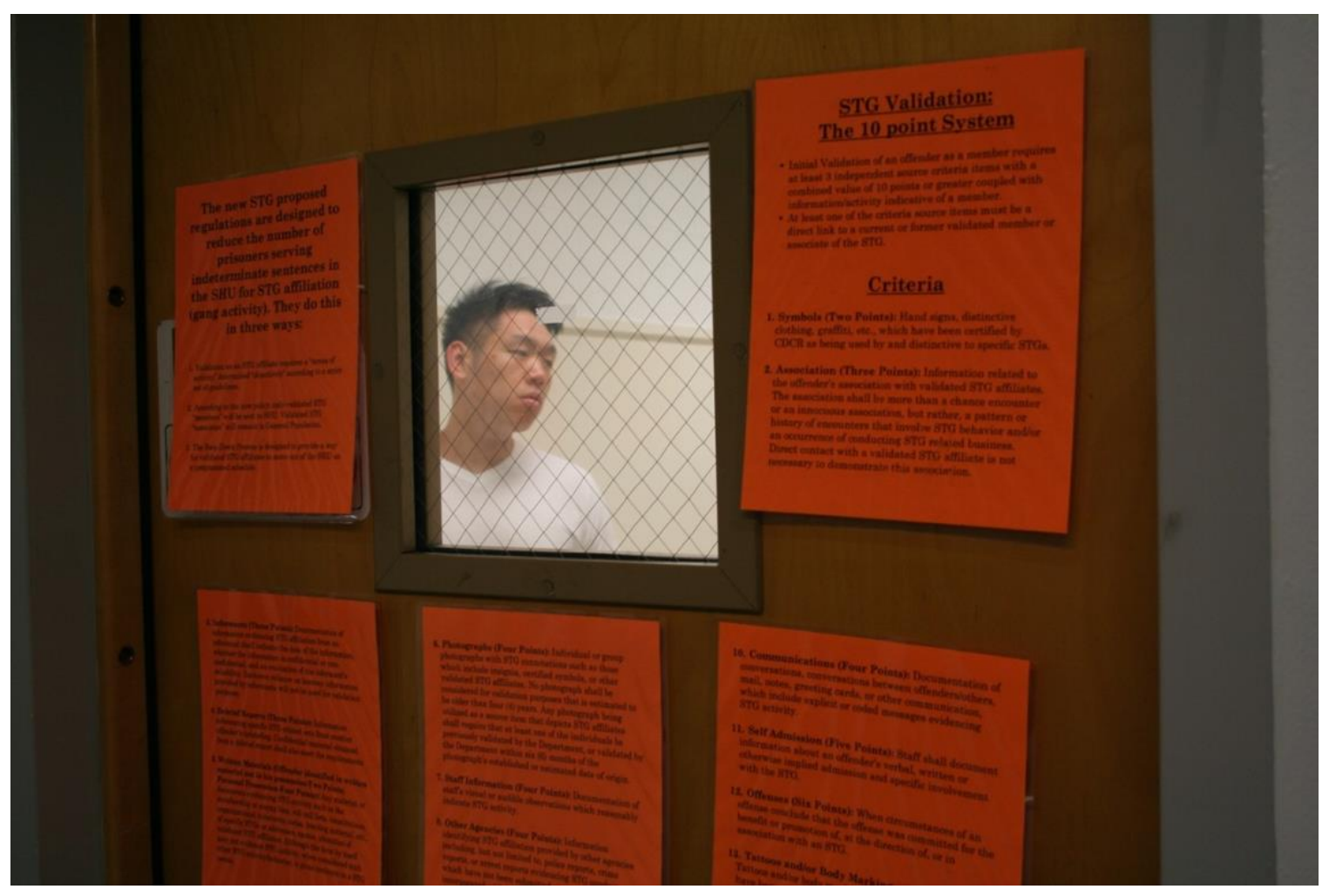

Figure 5. A Walk in Our SHUs: Solo performer and placards describing the debriefing process, photo by author

In contrast to the montage-like quality of the first performance, See You in My Dreams is a two-act epistolary play with one speaking character. From his cell inside Pelican Bay, Jack writes to Sheila about the hunger strike, life before imprisonment, his education, dreams, family, and life in the SHU. His letters are interspersed with interludes where he imagines activities such as dancing with a loved one, hosting a cooking show, singing with a rock band, or presenting a lecture series about his artwork. An ensemble of seven actors took turns portraying Jack as he experienced frustration, elation, and despair while working to maintain his sanity and sense of self. A design team comprised of students, faculty, and theatre professionals created the set, lighting, projections, sound, and costumes for the production. 


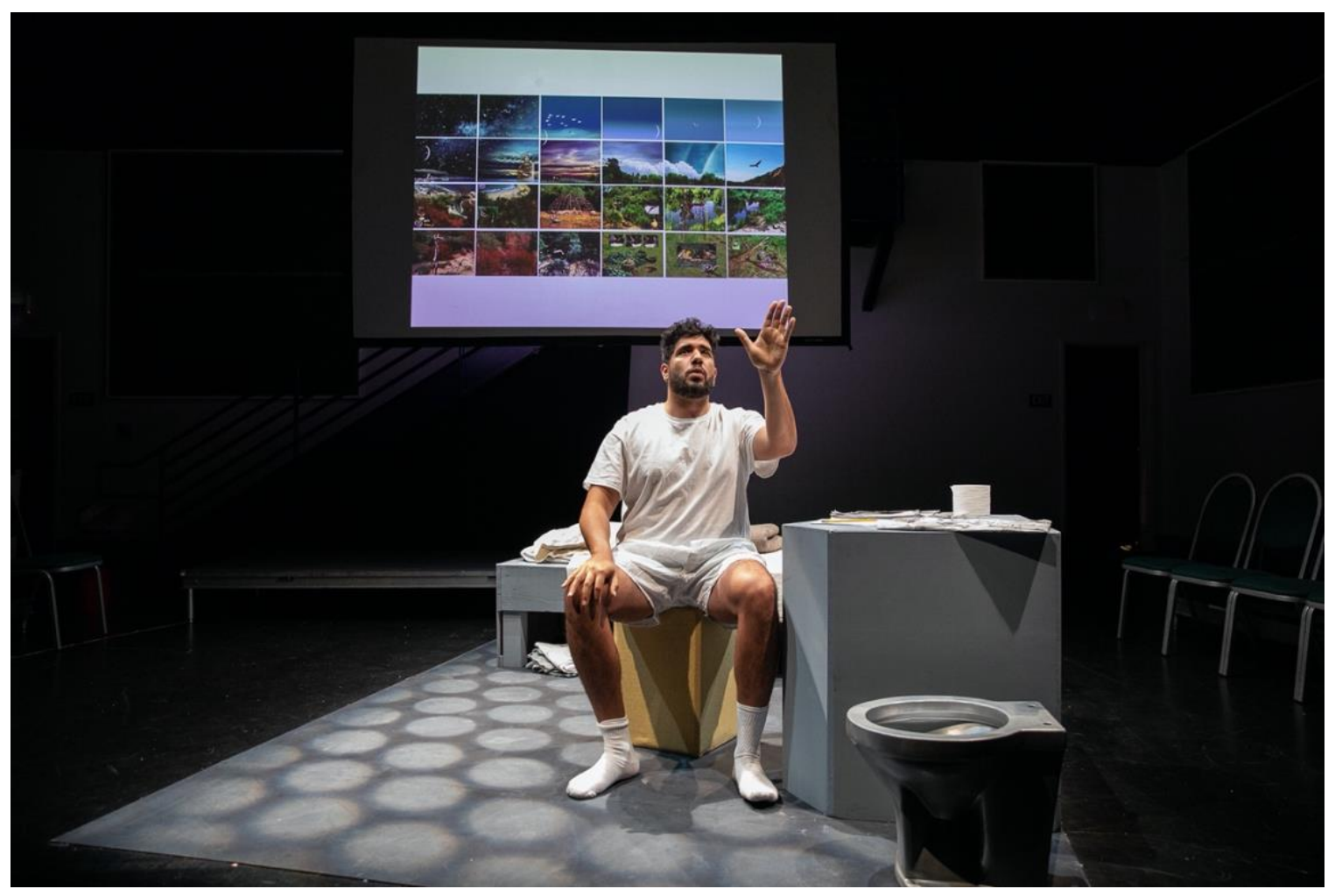

Figure 6. See You in My Dreams: Jack, photo by (C) Peter Merts.

Between 2014 and 2019 California's correctional system had undergone several changes. Most significantly, in 2016 the CDCR reached an historic settlement that (nominally) ended the practice of indeterminate sentencing. Jack Morris, along with thousands of other SHU residents, was released into the general prison population. Then, in September 2017, Jack was paroled. He moved to Los Angeles and began working as a community health worker for a public clinic. To my students' delight and trepidation, Jack and Sheila were able to attend the performance and participate in a talkback after the show. In their final reflections, many students described feeling both privileged and accountable to Jack and Sheila:

With the play's creation, everything felt more tangible, especially since we actually got to interact with Jack. We were all working hard to tell his story and through this, we formed a connection with him and each other.... I actually believe that having this class as a play was a key reason as to why I learned so much about solitary confinement. With the connections that we had together as a 
cast and crew and knowing that this was Jack and Sheila's actual story, I felt like we all had a passion to ensure that it's done correctly. ${ }^{24}$

I will never forget the experience and transformative discussions I shared with my classmates, my professors, our guest speaker, and of course Sheila and Jack. The course [is] unlike another other I've taken during my Undergrad study because it felt like I was working on something bigger than myself. ${ }^{25}$

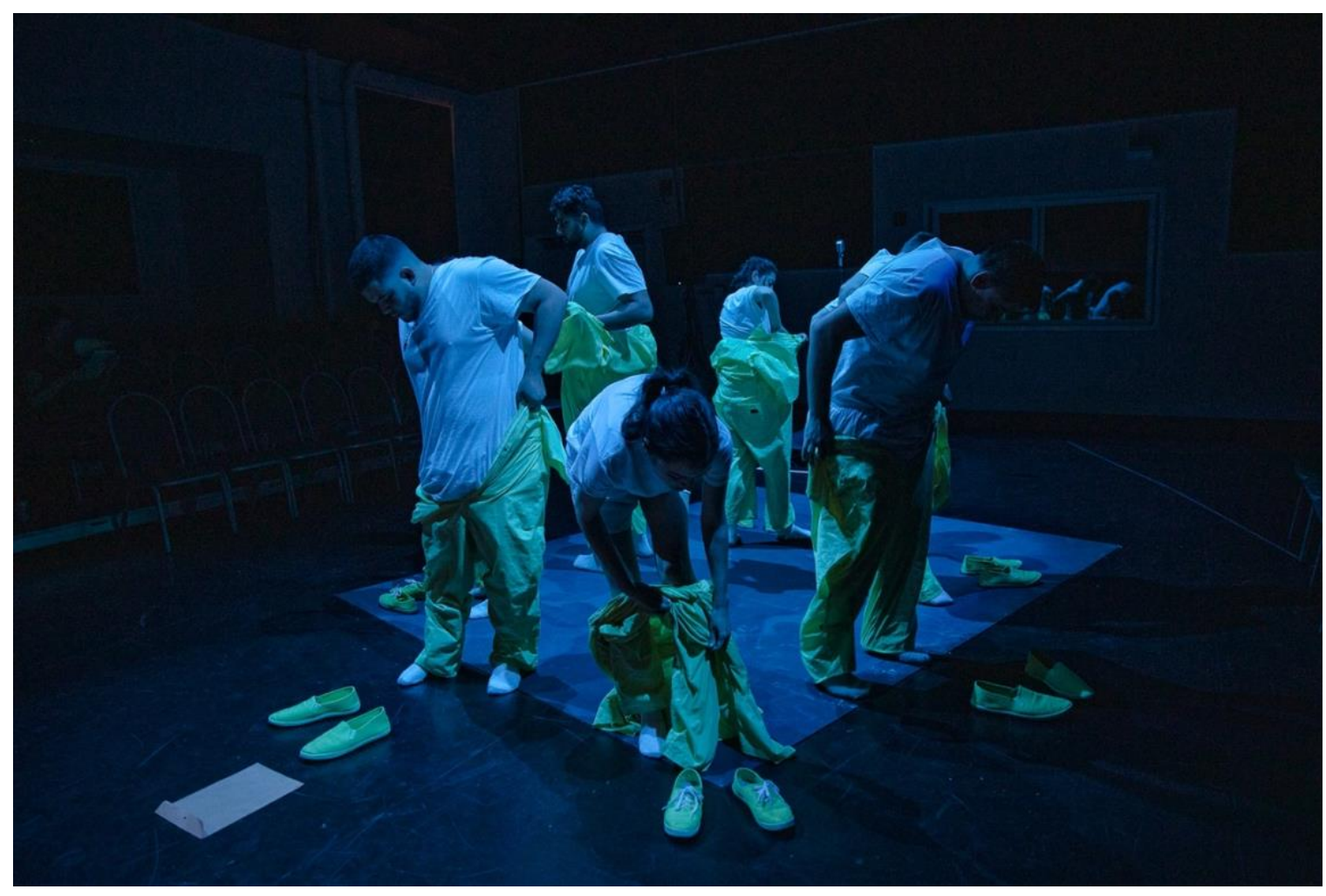

Figure 7. See You in My Dreams: Prologue, photo by @ Peter Merts.

While the dramaturgy, acting style, and mise en scène of See You in My Dreams could not be described as realism, the performance employed a traditional distance between the audience and performer. I was therefore struck by many students' comments about audience engagement.

A woman was shocked to learn that the size of the cell on stage was the same exact size Morris was confined to for $22 \frac{1}{2}$ hours a day. Another audience member inquired how Morris keep his sanity after his years in confinement. The 
question and answer segment after the play goes to show what we hoped to accomplish. We wanted the audience to be critical about what they had just seen. To question and begin to understand what they may not have known. ${ }^{26}$

Looking at the crowd react in various ways to the different letters was an experience in itself. Through their emotions I gained a deeper understanding of the criminal justice system as I saw the impact that Jack's words had on them. ${ }^{27}$ The feelings and thoughts articulated by the COMM 125P students echo artist Michelle Young's description of sharing oral histories after a devastating event in an Irish housing complex, where the shape of the show "seemed to favor a communal theatrical experience over a personal ownership and that challenged me to explore how, in the presentation of the lived experience of real people, the ownership of the performed narrative is affected by, or affects, the artistic process of performing it." ${ }^{28}$ Students seemed profoundly moved by the impact of Jack's words on the audience, and their awareness of themselves as the vessels delivering those words. This, in turn, impacted their performances, demonstrating a more dialogic relationship between audience and performer than I had anticipated.

Any principles of composition may be used to develop a successful PAR pedagogy, but instructors must be aware of the implications of their formal choices. The two versions of COMM 125P offered students very different PAR models (see table 3.) In the former, students conducted self-guided research and composed creative work that analyzed or responded to that research. In the latter, Jack's story and the opportunity to meet and talk to him and other solitary survivors gave students a concrete and emotional connection to the issue. Performing a story about a real person also offered a valuable entré to conversations about the ethics of representation. On the other hand, the majority of the dramaturgical content was relayed through spoken or written text, rather than experienced and interpreted through performance practice. While the performing students and designers found ways to play and experiment physically when working with the script, students in other roles had significantly less somatic engagement with the material. 
Script Performance is composed of solo performances created by Performance is a scripted play that individual students and material interludes. generated during in-class workshops.

Structure Performance is divided into three Performance includes a diversity of acts. The multiple short pieces formats (song, poetry, movement, within each act reflect a diversity solo and group work) supporting a of formats (song, poetry, central linear narrative following a movement, solo and group work, single character.

etc.), but are unified by a common theme.

Performance Acting is presentational and does Rehearsals emphasize volume, style not aspire to emotional realism. diction, and stage presence. Performers embody "personas" Comprehension and connection with or perspectives rather than the text is prioritized over emotional characters. realism. Extensive and accurate memorization is required.

Relationship Performance requires audience Performance imagines a fourth wall. to audience interaction.

Production "Shoestring" aesthetic, with Design aesthetic is spare but design minimal or suggestive costumes technically complex. and props. 


$\begin{array}{lll}\begin{array}{l}\text { Student } \\ \text { participation }\end{array} & \begin{array}{l}\text { All students have at least one } \\ \text { performance task and one } \\ \text { production task. }\end{array} & \begin{array}{l}\text { Students' responsibilities vary } \\ \text { depending on their role (actor, } \\ \text { ASM, costume. designer, etc.) }\end{array} \\ \text { Artistic } & \begin{array}{l}\text { Creative decision-making, } \\ \text { including assembly of the show }\end{array} & \begin{array}{l}\text { Creative decision-making is a } \\ \text { collaboration between the director }\end{array} \\ & \text { and casting, is done by the } & \text { and playwright. }\end{array}$

\section{From "know-what" to "know-that": Student Reflections}

In establishing a protocol for rigorous PAR practice, Nelson references three modes of comprehension: know-how, know-what, and know-that. My understanding of these modes can be explained with an example: "knowing how" to ride a bike is about ability; it is a skill that I have performed and can independently replicate. It is also about experience; riding a bike gives me access to specific feelings and sensations that are unique to me. By contrast, "knowing what" is about recognition; it involves my hypothetical awareness that there is such an activity as riding a bike, my ability to identify instances where I observe someone riding a bike, to describe the action of riding a bike, and even to recollect the experience of riding a bike. Finally, "knowing that" regards implications, which means understanding bike riding within a broader context. While the scope of context might vary, implications should be generalizable (to invoke the specter of the Institutional Review Board) and might include cycling's benefits for the environment, the history of bicycle design, or a collective understanding of the exhilaration experienced riding down a hill with the wind in one's hair.

Nelson advocates "establishing resonances" between knowing-what and knowingthat. ${ }^{29}$ She envisions "a shift through intersubjectivity into the know-what of shared and corroborated soft knowledge, in turn resonating with the harder know-that of established conceptual frameworks. ${ }^{30}$ This dance implies mutuality and circular engagement, but also a push towards explication and the legitimation of embodied experience through scholarship. For Nelson and many other PAR scholartists, this alchemy is achieved 
through writing. Lynette Hunter's observation that PAR resides "on the edge of articulacy," gestures to both its power and its pitfalls as a mode of inquiry. ${ }^{31}$ Nelson concedes that an experience or sense of knowing may not be successfully or fully communicated. Nonetheless, she cautions against claiming that the experience is untranslatable, emphasizing that critical reflection is important if PAR is to have a "discernible pedagogy." 32

In 2014, I asked students to write about the development of our final performance. Although the prompt required them to discuss theories of group communication, the reflections yield a "convergence of evidence" regarding the experiential nature of the PAR process. ${ }^{33}$ As one student noted,

These theories on social interaction are great, and I appreciate what the many people have done for our area of study, but I still hold true belief that the lessons learned rooted in social group interaction can truly only be learned through first hand experience, as seen in class. ${ }^{34}$

Students from 2019 were equally emphatic that the value of the course lay in its practical nature. They also recognized the limitations of their own research process:

Early on in the semester when we met in class, I quickly learned how little I truly knew about criminal justice in California...I think it would be unjust to ever say that anyone has had a full perspective of the criminal justice system because so many people are involved, so many lives changed. See You In My Dreams is a portrayal of just ONE man's life in solitary confinement. ${ }^{35}$

In April 2019, when all Californians were ordered to shelter in place in response to a global pandemic, I received an email from a student who had performed in See You in My Dreams. Free time and solitude had turned her thoughts towards Jack.

This got me thinking about the current situation, and wondering how Jack is feeling about being in a different kind of isolation. I had quickly made the comparison when it all started, and was able to help some of my friends by advising them to create a routine and spend time creating art to survive the monotony and stir-crazy feelings, inspired by Jack's experience. ${ }^{36}$

I was struck by the student's ability to readily translate the knowledge she gained from inhabiting Jack's body in performance into a shareable action for the benefit of others. 
Research about solitary had been transformed into research for a global pandemic. While this is not an application we might wish for, it speaks to the lasting power of her embodied experience.

In COMM 125P, student reflections served a dual purpose. For the scholartists-intraining, reflections "close the loop" by asking them to draw conclusions about their work. By moving away from what it felt like for them and what it might mean for others, students begin to regard their work not necessarily from an objective standpoint, but as Nelson says, they are nudged in the direction of objectivity. ${ }^{37}$ Reflections also allow the instructor to assess whether learning goals have been achieved and how course design can be improved. As discussed earlier, it was the 2014 student reflections that inspired me to attempt deeper student engagement with the course theme in the second version of the course.

As the editors of this journal have written, it is both a premise and goal of PAR that "knowledge formed through the material process of performance can be valued as equivalent to knowledge produced through speculative and analytical modes." 38 Writing is central to this legitimizing process, and it is therefore vital that sufficient time and care are provided for students to reflect on their work. If it is true, as Nelson asserts, that knowing is "a continuing process of negotiation between the various modes," the final reflection--and not the performance that precedes it--should serve as the course's culminating experience. ${ }^{39}$

\section{Conclusion}

As I continue to refine my approach to PAR pedagogy, Nelson's scholartistic tenets have provided an essential framework for synthesizing the experience of copresence with my students and many hours of critical reflection and conversation with colleagues. Below I sketch the principles/best practices I plan to implement moving forward, with the knowledge that they will continue to evolve (see table 4). In addition to Nelson's three elements, I have added an item related to the ethics of representation. Because I am conceiving of these as goals for my own teaching, I have structured them like the student learning outcomes described earlier. 
Making the Tacit Explicit

Compositional Principals

Connecting "know-what" to "know-that"
In learning outcomes and in conversation with students, EMPHASIZE the role of embodied activity throughout the three stages of the research process (collection, interpretation, and dissemination of data/evidence/material);

SPECIFY explicit compositional requirements for students to create original solo and group work;

STRATEGIZE about compositions that will best achieve learning outcomes and/or engagement with a specific topic;

POSE questions that inspire students to reflect critically on their process;

PROVIDE ample time throughout and at the end of the term for them to write and to share their thoughts with peers;

COMPLIMENT the "telling" inherent in the instructional actions on this list with activities that allow students to experience the "how" as well as the "that;"

Developing an ethical practice 
CHALLENGE students to think about authorship, access, and accountability for their work.

It is my hope that these tenets can help teachers to scaffold PAR for novice practitioners while remaining flexible enough to adapt to diverse scholartistic practices. For better or worse, many of those who teach classes that culminate in public presentations are evaluated on the "success" of the final product, whether that be aesthetic or, in the worst cases, commercial. It can be difficult to set aside these assessments, which can have implications for our employment and are often made by individuals unfamiliar with the myriad ways we work. Reflecting on pedagogical strategies and learning outcomes is not only a way to bring our attention back to the process of making, but can provide a method for making our teaching legible and meaningful to those outside our discipline(s).

\footnotetext{
${ }^{1}$ Keramet Reiter, "The Pelican Bay Hunger Strike: Resistance within the Structural Constraints of a US Supermax Prison," The South Atlantic Quarterly 113, no. 3 (Summer 2014): 582.

2 "Faces and Voices from the Hunger Strike," Prisoner Hunger Strike Solidarity, accessed May 15, 2020, https://prisonerhungerstrikesolidarity.wordpress.com/education/.

3 “Solitary Confinement Should Be Banned in Most Cases, UN Expert Says," UN News Centre, last modified October 18, 2011, https://news.un.org/en/story/2011/10/392012solitary-confinement-should-be-banned-most-cases-un-expert-says.

${ }^{4}$ Jessica Pishko, "The End of Solitary Confinement," Pacific Standard, last updated June 14, 2017, https://psmag.com/news/the-end-of-solitary-confinement.

${ }^{5}$ Robin Nelson, "Conceptual Frameworks for PAR and Related Pedagogy: From 'Hard Facts' to 'Liquid Knowing,", in Practice as Research in the Arts: Principles, Protocols, Pedagogies, Resistances, ed. Robin Nelson (Basingstoke: Palgrave Macmillan, 2013): 52.

${ }^{6}$ Shannon Jackson, "When is Art Research?” in Mapping Landscapes for Performance as Research: Scholarly Acts and Creative Cartographies, ed. Lynette Hunter and Shannon Rose Riley (New York: Palgrave, 2009): 158.
} 
${ }^{7}$ While Jackson does not specify the methods she locates under the umbrella of social science, I take her to include observation, ethnography, interviews, experimentation, and case studies.

8 This is not to say we are always successful in persuading colleagues outside our department of the value of our scholartistic accomplishments, particularly during evaluation for retention, tenure and promotion. However, Jackson's observation suggests we may meet less resistance when we claim our creative work as scholarship than do our colleagues in the Department of Film and Theatre and the School of Music and Dance, both housed in the College of Arts and Humanities.

9 "Learning Outcomes," Undergraduate, Department of Communication Studies, College of Social Sciences, San José State University, last accessed September 27, 2020, https://www.sjsu.edu/comm/undergraduate/ba/learning-outcomes.php.

10 Anonymous Student 1, "Final Paper," May 22, 2014.

11 “COMM 125P - Ensemble Performance," 2020-2021 Academic Catalog, San José State University 2020-2021

https://catalog.sjsu.edu/preview_course_nopop.php?catoid=2\&coid=6944.

12 Nelson, 52 (quoting a phrase often used by performance artist Marina Abramovic).

${ }^{13}$ Marilyn Arsem, "Performed Research: Audience as Investigator," in Mapping Landscapes for Performance as Research: Scholarly Acts and Creative Cartographies, ed. Lynette Hunter and Shannon Rose Riley (New York: Palgrave, 2009), 206-213. I taught COMM 125P twice between the two courses described here, once exploring homelessness in Silicon Valley and once on the topic of dating in the $21^{\text {st }}$ century. The final performances for both of these classes followed the compositional principles established in 2014.

${ }^{14}$ Nelson, 50-56. For a more in-depth discussion of doctoral study, see Lynette Hunter, "Valuing Performance/Practice as Academic Knowledge," in Mapping Landscapes for Performance as Research: Scholarly Acts and Creative Cartographies, ed. Lynette Hunter and Shannon Rose Riley (New York: Palgrave, 2009): 199-205.

15 The assignment echoed other immersive activities that attempt to evoke the physical experience of incarceratin, including mobile models of SHU cells used by the activist groups Sin Barras and California Prison Focus, or the chance to stand inside a jail cell during tours at historic prison sites Alcatraz (CA) and Eastern State Penitentiary (PA).

16 Anonymous Student 3, "Solitary Confinement Reflection,” February 11, 2014.

17 Anonymous Student 4, "Solitary Confinement Reflection," February 11, 2014.

18 Anonymous Student 5, “Solitary Confinement Reflection,” February 11, 2014.

19 Anonymous Student 6, "Solitary Confinement Reflection," February 12, 2014.

${ }^{20}$ Anonymous Student 7, “Communication Development," May 20, 2014.

21 Theoretical formulations are offered in Gloria Anzaldua's Borderlands: The New Mestiza (San Francisco: Aunt Lute Books, 1987); Paul Connerton's How Societies

Remember (Cambridge: Cambridge University Press, 1989); Diana Taylor's The Archive 
and the Repertoire: Performing Cultural Memory in the Americas (Durham: Duke University Press, 2003); and Joseph Roach's Cities of the Dead: Circum-Atlantic Performance (New York: Columbia University Press, 1996), to name a few. In addition, memoir, fiction, and nonfiction from writers such as James Baldwin, Eli Clare, Cherrie Moraga, and Toni Morrison offer personal accounts of embodied knowledge. There has also been a recent wellspring of literature on the idea of embodied knowledge across many subject areas, enabling instructors to select readings that apply directly to the course's specific area of inquiry.

22 Jackson, 161.

23 Anonymous Student 2, "Family," May 19, 2014.

${ }^{24}$ Anonymous Student A, "Final Reflection," May 15, 2019.

${ }^{25}$ Anonymous Student B, "Final Reflection," May 16, 2019.

${ }^{26}$ Anonymous Student C, "Final Reflection,” May 15, 2019.

27 Anonymous Student D, "Final Reflection," May 16, 2019.

${ }^{28}$ Michelle Young, "Speak for Yourself: Considerations of Ethics and Aesthetics in the Performance of a Community Oral History Project," PARtake: The Journal of

Performance as Research 1, no. 2 (Summer 2017): 2-3, https://journals.colorado.edu/index.php/partake/article/view/365/345.

${ }^{29}$ Nelson, 52.

${ }^{30}$ Ibid., 60.

${ }^{31}$ Hunter, 201.

${ }^{32}$ Nelson, 48.

${ }^{33}$ Ibid., 65.

${ }^{34}$ Anonymous Student 8, “Group Communication,” May 20, 2014.

35 Anonymous Student E, “Final Reflection,” May 16, 2019.

${ }^{36}$ Erica Smith, Email message to author, April 28, 2020.

${ }^{37}$ Nelson, 60. Nelson follows Thomas Nagel's model of a continuum between subjectivity and objectivity; see Thomas Nagel, The View from Nowhere (New York, Oxford University Press, 1986).

${ }^{38}$ William W. Lewis and Niki Tulk, "Editorial: Why Performance as Research?" PARtake: The Journal of Performance as Research 1, no. 1 (Fall 2016): 1, https://journals.colorado.edu/index.php/partake/article/view/325/297.

${ }^{39}$ Nelson, 58. 